\title{
Factors Associated with Low Virulence in the Infective COVID-19 Virus in Africa with the Pandemic infection Rise
}

\section{Maurice B Silali*}

Maseno University, Kenya

*Corresponding Author: Maurice B Silali, Maseno University, Kenya
Received: March 26, 2020

Published: April 01, 2020

(c) All rights are reserved by Maurice B Silali.

\begin{abstract}
Distribution and determinants of low virulence in the contagious/communicable COVID-19, among the population health of the black race of Tropical climate remains unclear, since its discovery in Wuhan China 2019. We define Health from the World Health organization, (WHO) definition of 1948 [11] which is now terrorizing most societies of the World to remain into the vicious cycle due to persistence skewed economy, poverty and illness. In February 2020, WHO re named COVID novel Corona or Wuhan china virus, which is air borne disease that may remain viable in the environment for over 8hrs susceptible to population health, due to its attributed global pandemic infection with varying virulence among the various continents. COVID-19 is caused by a virus similar to the Severe Acute Respiratory syndrome - COV-2 [SARS] of (2002), of the animal reservoir Bats, that was spread by the intermediate host (civet cats), and also first discovered in southern China in 2002. The reservoir host for COVID-19 virus is also Bat animal which when spread to the intermediate host, Pangolin animal [ant heater], it undergoes the gene mediation that is potentially infectious to population health. The incubation period of COVID-19, [time interval of exposure to agent of infection to onset of symptoms] of COVID-19, ranges from 5 to 24 days, when inhaled or comes in contact with the susceptible human population. The onset of signs and symptoms may include: fever [pyrexia], sneezing, short breath for mild cases, while susceptible host may develop severe symptoms such pneumonia and septic shock due to entry of the viruses into blood vessels and severe conditions are common to population health of cohort age above 60 years and above, hypertension and diabetic mellitus population. The Current treatment of COVID-19, is basically supportive care which involve provision of intra venous fluids to replenish the lost body fluids besides regular medication Chloroquine tablets used to treat malaria, Ritovir for HIV and Remdesivir used to treat Ebola cases in 2014 which were used to manage COVID 19 in Wuhan china in 2020. Despite the fact that COVID-19 has high infection to population health its Virulence remain low specifically in Black race located in tropical Africa compared other corona virus such SARS, and Ebola whose virulence is deadly to population health.

Keywords: COVID-19; Air Borne; Hand Washing; Infection; Virulence; Immunity; Supportive Care; Tropical Climate
\end{abstract}

\section{Introduction and Background Information}

Normally the population health in any society contain various corona virus in their respiratory tract, which are closely associated with common colds or flu colds infections in most parts in tropics an the Sub Saharan Africa, Kenya included. However the mediated strains of corona virus that circulates in the Bat, animal reservoir and intermediate host, Pangolin causes infection, when inhaled or come in contact by the susceptible human population, which is more virulence in white race than the black race as demonstrated from the recent WHO global data on COVID-19 from the global data from global social media content analysis, 2020 [5,12].

At this particular point in time of the COVID-19, its virulence may be only be determined in relation to type of race that is more susceptible to COVID-19 agent, in relation to may their genetics composition, level of melanocytes and epidermal keratinocytes, co-morbidity of virus in the population per content, biology set up of the mediated COVID-19 virus, its level of chemical toxin injected in the susceptible host, physical trauma caused on lining of the lung, mode of nutrition and environmental factors of the susceptible population health, $[5,17]$. This study aimed to elucidated and enhance the role of epidemiologist in holistic implementation: quality public health surveillance on epidemic investigation, holistic case analysis, evaluation of the magnitude of the COVID-19 virulence to its population, raise $\mathrm{n}$ alert to the society [7], put quarantine measures to health population and isolation measures only to confirmed COVID-19 individuals who are potentially infectious [16]. Provide strict ban measures on both internal and external travelers to and from the infected epidemic states to protect our own citizens via proper health education and promotion information and communication through a sector wide approach system and team work to contain the pandemic transmissions $[5,8]$. Then need to determine and control the candid mode of transmission/ risk factors of COVID-19, in the population health influence the countries social economic development, within the era of the COVID-19 monitor and evaluate the impact of the step missed out in governance on the future generation to sustain a health society and a wealth nation $[5,18]$. 
Material and Methodology

Epidemiologic triad of the pandemic COVID-19

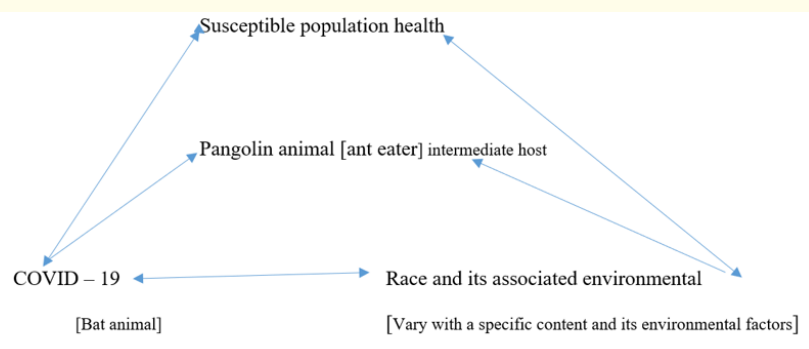

Figure 1: Source: [WHO, 2019].

The time interval of COVID-19, from exposure to onset of signs and symptoms in the susceptible population with infection vary from (5 to 24) days. Advantage of the virus is that is highly infectious but its virulence in the susceptible population is limited or low, which is attributed to the low case fatality rate demonstrated in WHO data, March 2020, with a marked pandemic infection. The low case fatality rates among the black race as demonstrated from content analysis of the recent retrospective data from WHO, global social media data and observation survey gathered via 3Ls, (look, listen and learn) from the trends of the population health/wellbeing of the society in a pandemic COVID-19 infection $[4,12]$.

The current resistant of black race against COVID-19, with Ro $>1$ may be associated with high quality of melanocytes and epidermal keratinocytes for absorption of vitamin D and enhanced wound healing respectively than in the white race, besides suspected presence of long life passive immunity [2], got from the normal corona virus associated with the recurrent infective common cold or flu cold susceptible to black race in tropical climate, and majority of African births being given in ever air polluted environment with limited practice of quality hygiene and preventive medicine measures put in place thus good immunity against COVID-19. Most of African society has passion for curative medicine, thus COVID-19 is awake up call to empower and sustain the quality preventive medicine, because primary prevention is better than cure, especially among the current majority households struggling in the vicious cycles of poverty and illness to fulfill the daily live hoods [7]
Morphological characteristics of COVID-19

COVID-19 virus contains morphological characteristics similar to SARS COVD-2, of 2002 also isolated in China in 2003. Hence also called SARs corona virus. Can survive in hot regions of above $27^{\circ} \mathrm{C}$ and air borne disease [1].

COVID-19 is a single RNA virus with crown like protein spike that stick of lung organ in its severe cases to cause pneumonia, and physical trauma that results to bursting of the lung arteries and veins to cause septic shock. The rate of infection is determine by the race of the susceptible host, the environment, chemical toxin released by the COVID-19 and its biological mediated level of genes. The infection in the susceptible race, signs and symptoms varies from asymptomatic, mild, and severe to super spreaders, who have potential characteristics of high virulence like discordant partners in HIV but often remain asymptomatic in nature [4].

\section{Mode of transmission and pathogenesis}

Transmission COVID-19 virus is an air borne that can be transmitted at a longer distance in free air, but in droplet or sneezing form it can only spread at distance of $3 \mathrm{ft}$. or 1 meter from the infected person to susceptible population [9].

On dry surface area COVID-19, may die after 24 hrs thus why we encourage thorough hand washing and sanitation when mixed or crowded with suspected of COVID-19 contacts population or travel in the outbreak regions [5].

In the body the virus high affinity of enzyme Angio converting enzyme - 2 (ACE-2) locate on the alveolar cell to form its receptor on the lung tissue. The lung has 3 types of alveolar cells which include: type 1 responsible for gaseous exchange, type 2 are surfactant in nature and contain protein and fats that reduces surface tension of the lung. Type 3 are dust cells which are phagocytic in nature. COVID-19, contain a protein envelope called spikes that help the virus to bind on the receptor (ACE-2) and enhance virulence in the host after infection. The cell wall of virus is rounded by the spike that make it to resemble the crown.

The trend virulence trends in various infectious corona viruses in relation to COVID-19

\begin{tabular}{|l|c|c|c|c|c|c|c|c|}
\hline $\begin{array}{c}\text { Name of } \\
\text { Corona } \\
\text { virus }\end{array}$ & $\begin{array}{c}\text { Emergence } \\
\text { year }\end{array}$ & Morbidity & Mortality & $\begin{array}{c}\text { Fatality } \\
\text { rate } \\
\text { (\%) }\end{array}$ & State of origin & Spread & Virulence & Vaccine \\
\hline $\begin{array}{l}\text { COVID-19 } \\
{[16]}\end{array}$ & 2019 & 61063 & 2076 & 3.4 & China & Droplets contacts & Low & $\begin{array}{c}\text { Under } \\
\text { development }\end{array}$ \\
\hline $\begin{array}{l}\text { SARS 2002 } \\
{[13]}\end{array}$ & 2002 & 8,098 & 774 & 9.6 & China & Mainly contacts & Moderate & Under \\
development \\
\hline $\begin{array}{l}\text { MERs2012 } \\
{[4]}\end{array}$ & 2012 & 2494 & 858 & 34 & $\begin{array}{c}\text { Saudi Arabia } \\
\text { and Korea }\end{array}$ & $\begin{array}{c}\text { Strictly zoonotic: Direct } \\
\text { or indirect contact with } \\
\text { dromedaries camel } \\
\text { products }\end{array}$ & Moderate & Under \\
development \\
\hline $\begin{array}{l}\text { Ebola 2014 } \\
{[15]}\end{array}$ & 1976,2014 & 28639 & 11,316 & 40 & $\begin{array}{c}\text { West Africa, in } \\
\text { village near river } \\
\text { Ebola, DRC Congo. }\end{array}$ & $\begin{array}{c}\text { Direct contacts with } \\
\text { infected Ebola fluids }\end{array}$ & High & rVSV-ZEBOV \\
very effective \\
\hline
\end{tabular}

Table: Source: WHO, March, (2020). 
Reproductive rates of COVID-19

Reproductive rate is the number of new susceptible persons infected by each infective COVID-19 person [3] denoted as follows:

1. Ro $=1$ One infective COVID-19 person, infected one susceptible person in the community.

2. Ro $=6$ One infective COVID-19 person, infected 6 new susceptible persons in the community

3. $\mathrm{Ro}=20$ One infective COVID-19 person infected new 20 susceptible persons in the community

4. Ro $=50$ One infective COVID-19 person infected new 50 susceptible persons in the community like the initial case of Wuhan china before the control measures took place $[3,4]$.

Global trend of virulence in the susceptible population with infective COVID-19

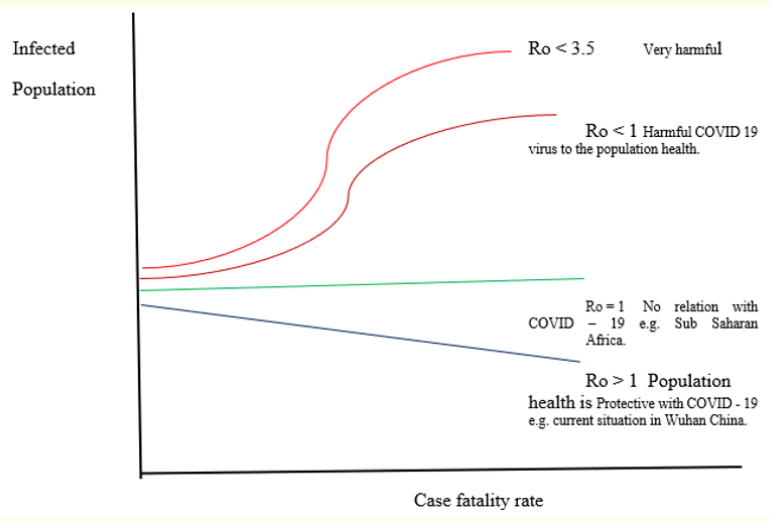

Figure 2: Source: [WHO, 2019].

\section{Laboratory diagnosis of COVID-19}

Basically, diagnosed by using the real time Polymerase Chain Reaction, [rtPCR], a technique used to make numerous copies of a specific segment of RNA quickly and accurately from a mixture of molecules [2]. First, two short RNA sequences called primers are designed to bind to the start and end of the RNA target [2]. Since COVID-19 is RNA virus, the RNA is extracted from the sample then purified before the enzyme reverse transcriptase is added in the substrate to convert RNA to DNA. DNA is mixed with primers, sections of DNA of designed to bind to characteristic parts of the virus DNA. Repeatedly heating then cooled DNA with the primers and a DNA building enzyme makes millions of copies of virus DNA.

To perform PCR, the DNA template that contains the target is added to a tube that contains primers, free nucleotides, and an enzyme called DNA polymerase, and the mixture is placed in a PCR machine. The PCR machine increases and decreases the temperature of the sample in automatic, programmed steps. Initially, the mixture is heated to denature, the single-stranded DNA template [2]. The mixture is then cooled so that the primers anneal, or bind, to the DNA template. At this point, the DNA polymerase begins to synthesize new strands of DNA starting from the primers. Following synthesis and at the end of the first cycle, each single-strand
DNA molecule consists of one new and one old DNA strand. PCR then continues with additional cycles that repeat the aforementioned steps. The newly synthesized DNA segments serve as templates in later cycles, which allow the DNA target to be exponentially amplified millions of times [2,4]. Main source of specimen for sampling the PCR test are serum and bronchoscopy biopsy [lavage], lung biopsies. Other sources of the sample may be sputum, swabs from the lung aspirates or stool.

\section{Treatment of the COVID-19}

Mainly managed by the supportive care which involve provision of intra venous fluids, oxygen ventilator for case of septic shock or lung damage by spike of COVID-19 virus [14], as you administer prophylaxis medicine: Chloroquine tablets for malaria, Ritonavir for HIV suppression [3] and Remdesivir used to manage Ebola disease [8]. Septic shock is characterized by presence of the following symptoms on the infected COVID-19 population: pyrexia of above $38^{\circ} \mathrm{C}$, drop of blood pressure (BP), fast heart beats, rapid breathing and cyanosis [9].

\section{Prevention of COVID-19}

1. No vaccine has been developed against the COVID-19 at the moment.

2. Avoid travel to and from the potentially epidemic areas.

3. Stay away from crowds.

4. Avoid use of face masks in crowed areas because the environment has minimal health risk.

5. Practice the preventive medicine of hand hygiene: Hand washing in plenty running tap water with soap or rinsing dry hands with sanitize (70\% ethyl alcohol and glycerin) to inhibit spread of COVID-19.

6. Avoid touching the potentially transmission three zones: Mouth lips, Ear and Eyes [T- zone] [16].

Prevention of COVID-19 droplets and contact precaution by health service providers

1. While in the facility or gone to pick suspected patient with COVID-19. Always wear of sterile surgical gloves and face masks.

2. Wear long sleeved gown.

3. Protect the eyes with $\mathrm{N} 95$ respirators when performing autopsies or procedures associated with production of the aerosols from COVID 19 infective corpse or patient respectively $[6,16]$.

\section{Results}

Graph demonstrate the outcome of COVID-19 infection rate against Virulence rate in relation to race

From the content analysis of the COVID-19 pandemic disease from WHO 2020 data given, it was noted to have large number of infection, across the two race with more virulence in white race than black race as clearly demonstrated in global morbidity , mortalities and varying case fatality from content to content. The results was also gathered from Transect walk in East Africa Communities using key informant interview which most attributed the 
level of melanocytes, keratinocytes African nutrition and plenty of tropical African climate that replenish vitamin D and C have great impact to black race long life immunity that mitigate the black race population from developing severe symptoms of COVID-19 among the Black race.

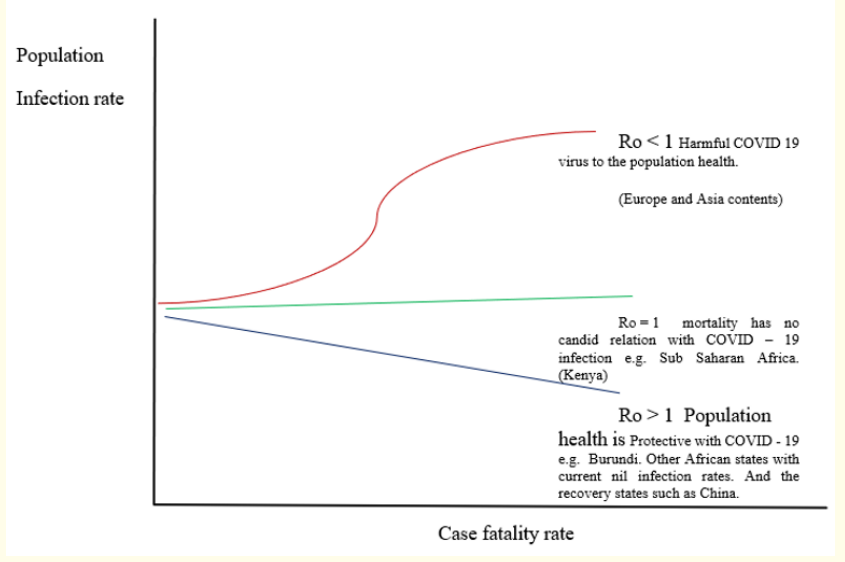

Figure 3

\section{Discussions}

Majority of corona virus located in the respiratory tract of human beings, causes benign communicable disease, which are closely associated with common colds or flu colds infections in the Tropical Africa and the sub Saharan Africa countries. COVID-19 is a single RNA virus with crown like protein spike that stick of lung organ in its severe cases to cause pneumonia, and physical trauma that results to bursting of the lung arteries and veins to cause septic shock. The rate of infection is determine by the race of the susceptible host, the environment factors, chemical toxin released by the COVID-19 and its biological mediated level of genes, the virulence in white race is higher than in black race which is contrarily to the study DR. Li Wenliang, from china who discovered the COVID novel Corona or Wuhan china virus 2020.

Since the reservoir organ of COVID-19 is the lung of the human being which contain 3 main types of lung cells: type 1 for gaseous exchange in alveoli, type 2 act as surfactant, contain protein and fats to stretch alveoli like the skin and type 3 are dust that cells act as macrophages against any pathogenic microbes, infection by COVID-19 causes negative effect of the physiology of the lung which is in line with the study by 2020 and study by Haines A and S Kuruvilla (2004).

\section{Conclusions}

Despite the fact that COVID-19 has high infection and moderate virulence in the white race population. Its Virulence remain low specifically in Black race located in tropical Africa which is closely associated with high passive immunity, African nutrition and Tropical climate with full. However, there is need to carry out further research why case fatality in white race in higher than African race in the relationship with geographical location, level of melanocytes and immunogenicity between black and white races.

\section{Bibliography}

1. Casona LM., et al. "Effect of high temperatures and relative humidity on corona virus survival on the dry surfaces" 76 (2019): 12-27.

2. Daniel JK. "In the Name of Eugenics: Genetics and the Uses of Human Heredity". University of California Press volume 2 (2012): 277-237.

3. Gradys D. "China begins testing of antiviral drugs to manage COVID-2 Corona virus" (2020).

4. Li Wenliang. "An alarm on the emergence of CoviD-2 corona virus in Wuhan china" (2019).

5. Haines A and S Kuruvilla. "Bridging the implementation gap between knowledge and action for health". Bulletin of the World Health Organization 82.10 (2004): 724-732.

6. Health Act. Section 80, In Kenya autopsies are required for purposes of aiding a legal process and state Planning purpose to create data base that help health sector for Policy formation page 8 and 9 (2017).

7. Singleton A., et al. "Approaches to social research". Oxford University, Press: New York (1998).

8. Southerland B. "Participation Research in Natural resources, social-economic". Trainer's Guide for Participatory learning and Action London (1998).

9. Leon Gordis. "Principles of epidemiology". Third edition (2004).

10. Wang., et al. "Redmsivir and chloroquine inhibits COVID 19 reproduction in vitro" (2020).

11. WHO. "Health, State of complete physical, mental, social, emotional, spiritual, and environmental well-being and not merely the absence of diseases or infirmity" (1948).

12. WHO. "Health challenges are influenced by bad health practices which forms major difficulty in achieving quality healthcare in developing countries" (1997).

13. WHO. "Effects of SARs on the population health in southern China" (2005).

14. WHO. "Middle East Respiratory Syndrome Corona virus, MERs- COVID out breaks in Saudi Arabia and Korea” (2012).

15. WHO. "Cost of management of Ebola disease in West Africa, epicene error" (2014).

16. WHO. "Preventive and treatment of the novel corona viruses in Wuhan china” (2019).

17. WHO. "Functional assessment of the cell entry and receptor usage for linear B. Beta corona virus” (2020). 
18. Wu J., et al. "Costing and forecasting the potential intervention on the spread of COVID 2019". Lancet (2020).

\section{Assets from publication with us}

- Prompt Acknowledgement after receiving the article

- Thorough Double blinded peer review

- Rapid Publication

- Issue of Publication Certificate

- High visibility of your Published work

Website: https://www.actascientific.com/

Submit Article: https://www.actascientific.com/submission.php

Email us: editor@actascientific.com

Contact us: +919182824667 